\title{
Ferric-reductase activities in whole cells and cell fractions of Vibrio (Listonella) anguillarum
}

\author{
Ramón Mazoy and Manuel L. Lemos
}

Departamento de Microbiologra y Parasitologra, Facultad de Ciencias, Universidad de Santiago de Compostela, Campus de Lugo, E-27002 Lugo, Spain

\author{
Author for correspondence: Manuel L. Lemos Tel: +34 82252231 ext. 22106. Fax: +34 82224904 . \\ e-mail:mlemos@seinl.usc.es
}

\begin{abstract}
The ability of Vibrio (Listonella) anguillarum strains from serotype groups 01 and $\mathrm{O2}$ to reduce $\mathrm{Fe}^{3+}$ in the form of different chelates was investigated. All strains, grown in M9 minimal medium supplemented with $0.2 \%$ Casamino acids, reduced $\mathrm{Fe}^{3+}$ complexed by citrate, nitrilotriacetic acid and EDTA. In whole cells, the degree of reduction was dependent on the $\mathrm{Fe}^{3+}$ ligand and on the strain, with the greatest values corresponding to ferric dicitrate and serotype group 01 strains, respectively. The ferric-reductase activity increased, over the basal levels, when the cells were grown with iron added as ferric dicitrate, haemin or haemoglobin. All strains also reduced ferricyanide, a compound that is not transported into the bacterial cells. Ferricyanide reduction was also increased when the cells were grown in the presence of an iron source. All of the cell fractions (periplasm, membranes and cytoplasm) showed Fe ${ }^{3+}-$ reducing activity, with the highest values observed in the presence of $\mathrm{Mg}^{2+}$, NADH and FAD in the assay buffer. Cytoplasmic ferricreductase could be visualized using native polyacrylamide or starch gel electrophoresis, whereas the periplasmic and membrane reductase(s) could only be detected on starch gels. The results indicate the presence of different ferric-reductase activities in $V$. anguillarum, which could be involved in the different iron-acquisition systems present in this micro-organism, i.e. siderophore-mediated systems and siderophore-independent mechanisms.
\end{abstract}

Keywords: Vibrio anguillarum, ferric-reductases, ferric dicitrate, iron uptake

\section{INTRODUCTION}

Iron is a basic mineral nutrient for all micro-organisms. However, the ferric form $\left(\mathrm{Fe}^{3+}\right)$, which is the main source in aerobic environments, is highly insoluble at physiological $\mathrm{pH}$ values (Neilands et al., 1987). Thus, microorganisms have developed different mechanisms to acquire sufficient iron for growth. One mechanism is the secretion of high-affinity, low-molecular-mass compounds known as siderophores, which are internalized through cell surface protein receptors (Crosa, 1989). Once inside the cell, iron must be released from the ferrisiderophore, and this is usually accomplished by means of a ferric-reductase. Ferrisiderophore reductase activities have been reported in several micro-organisms, and in some cases the enzyme has been isolated (Cox, 1980; Moody \& Dailey, 1983; Hallé \& Meyer, 1989).

Other micro-organisms do not appear to secrete siderophores, e.g. Saccharomyces cerevisiae. In this organism, a

Abbreviation: NTA, nitrilotriacetic acid. membrane ferric-reductase catalyses the transfer of electrons from cytosolic $\mathrm{NAD}(\mathrm{P}) \mathrm{H}$ to extracellular ferric chelates. The soluble $\mathrm{Fe}^{2+}$ produced is then transported into the cell (Lesuisse et al., 1987, 1991). Reductase activities in membranes have also been described in other micro-organisms, such as Spirillum itersonii (Dailey \& Lascelles, 1977), Staphylococcus aureus (Lascelles \& Burke, 1978) and Escbericbia coli (Fischer et al., 1990). Thus, in several micro-organisms ferric-reductases could be important to reduce siderophore-bound iron or to acquire it from soluble ferric complexes, including ferric citrate (Johnson et al., 1991).

In Vibrio (Listonella) anguillarum, one of the most important marine fish pathogens, two different mechanisms of iron acquisition mediated by siderophores have been described in pathogenic strains belonging to serotype groups O1 and O2 (Lemos et al., 1988; Crosa, 1989). The utilization of haem-containing compounds as iron sources has also been reported in this micro-organism (Mazoy \& Lemos, 1991, 1996). The involvement of reductases in the iron-uptake process by these different mechanisms is thus 
far unknown. Our goal in the present work was to analyse the presence of ferric-reductase activities in whole cells and different cellular fractions from $V$. anguillarum strains belonging to the main pathogenic serotype groups $\mathrm{O} 1$ and $\mathrm{O} 2$.

\section{METHODS}

Bacterial strains and culture conditions. $V$. anguillarum strains 775(pJM1) and H775-3 (plasmidless derivative of 775) of serotype group O1, and strains RV22 (serotype group O2) and NG-6 (siderophore-deficient derivative of RV22) have been described previously (Lemos et al., 1988; Conchas, 1994). Cells were grown aerobically at $25^{\circ} \mathrm{C}$ with shaking at 170 r.p.m. in flasks containing M9 minimal medium (Miller, 1972) supplemented with $0.2 \%$ Casamino acids (Difco; CM9) or in CM9 with $5 \mu \mathrm{M}$ iron added as ferric dicitrate, haemin or haemoglobin. Cells were harvested by centrifugation at the stationary phase of growth (about $10^{9}$ c.f.u.), washed, resuspended in the same medium, and assayed for ferric-reductase activities.

Preparation of cell fractions. The method described by Angerer et al. (1992) was slightly modified and used to release the periplasm fraction and produce spheroplasts. Bacterial cells grown in CM9 (with or without iron added as ferric dicitrate, haemin or haemoglobin at final concentrations of $5 \mu \mathrm{M}$ ) were resuspended in $0.19 \mathrm{M}$ Tris, $0.21 \mathrm{M}$ sucrose and $0.5 \mathrm{mM}$ EDTA ( $\mathrm{pH} \mathrm{8.0)} \mathrm{with} \mathrm{lysozyme} \mathrm{at} 0.5 \mathrm{mg} \mathrm{ml}^{-1}$. The cell suspension was incubated on ice for $5 \mathrm{~min}$ and $\mathrm{MgSO}_{4}$ was added to a final concentration of $0.02 \mathrm{M}$. The cell suspension was then centrifuged at $10000 \mathrm{~g}$ for $30 \mathrm{~min}$ at $4{ }^{\circ} \mathrm{C}$. The supernatant contained the periplasm and the pellet contained the spheroplasts.

The cytoplasmic and membrane fractions were isolated by disruption of these spheroplasts in $0.19 \mathrm{M}$ Tris, $0.21 \mathrm{M}$ sucrose, $0.5 \mathrm{mM}$ EDTA and $0.02 \mathrm{M} \mathrm{MgSO}_{4}(\mathrm{pH} \mathrm{8.0}$ ) (buffer $\mathrm{A}$ ) by sonication on ice. The sonicated suspension was centrifuged at $10000 \mathrm{~g}$ at $4^{\circ} \mathrm{C}$ for $5 \mathrm{~min}$ to remove whole cells and cellular debris. The supernatant was then centrifuged at $80000 \boldsymbol{g}$ for $60 \mathrm{~min}$ to obtain the membrane (pellet) and cytoplasmic (supernatant) fractions. Membrane fractions were washed twice in the same buffer and centrifuged again. All fractions were used immediately after preparation.

Assay of ferric-reductase activities in cell fractions. The reduction of $\mathrm{Fe}^{3+}$ was assayed with ferrozine [3-(2-pyridyl)-5,6bis(4-phenylsulfonic acid)-1,2,4-triazine] (Sigma) as $\mathrm{Fe}^{2+}$-trapping reagent (Dailey \& Lascelles, 1977). Ferrozine is water soluble and does not react with $\mathrm{Fe}^{3+}$. The ferrous complex of ferrozine has an absorbance maximum at $562 \mathrm{~nm}$ and a molar extinction coefficient of 27900 (Stookey, 1970).

The reaction mixture contained (in a final volume of $2 \mathrm{ml}$ ): $1 \mathrm{ml}$ cell extract, $12.5 \mu \mathrm{M}$ iron as ferric dicitrate, ferric-nitrilotriacetic acid (ferric-NTA), ferric-EDTA or ferric chloride; $250 \mu \mathrm{M}$ ferrozine; $250 \mu \mathrm{M}$ NAD, reduced form (NADH; Sigma). In some experiments, FAD (Sigma) was added to a final concentration of $50 \mu \mathrm{M}$. The reference cuvettes contained all of the reagents except iron. The assay was performed at $24{ }^{\circ} \mathrm{C}$ in polystyrene cuvettes in order to minimize non-enzymic reduction (Cox, 1980) and was monitored at $562 \mathrm{~nm}$ in a Hitachi U-2000 double-beam spectrophotometer.

Measurements of enzymic stability were made by heating each cell extract at $95^{\circ} \mathrm{C}$. After incubation for $15 \mathrm{~min}$, the extracts were cooled in an ice-bath, equilibrated to $24^{\circ} \mathrm{C}$, and then tested for ferric-reductase activities. Specific activities in each cell fraction were calculated as the amount of product formed (mg protein) ${ }^{-1} \mathrm{~min}^{-1}$. The results represent the means of four experiments performed in duplicate.
In some experiments, the following inhibitors were added as $100 \times$ solutions: $20 \mathrm{mM} \mathrm{NaN}_{3}$ (Sigma); $10 \mathrm{mM} \mathrm{2,4} \mathrm{dinitro-}$ phenol (DNP; Sigma). These inhibitors were also used to treat growing cultures of bacteria.

Ferric-reductase activities of whole cells. Ferric-reductase activities of whole cells, grown, washed and resuspended in CM9, were assayed spectrophotometrically with ferrozine (final concentration of $250 \mu \mathrm{M})$ and iron $(12.5 \mu \mathrm{M})$ as ferric dicitrate, ferric-NTA, ferric-EDTA or ferric chloride. Since ferrozine is sulfonated, it would not be expected to readily traverse the cell membrane and only reduction of external $\mathrm{Fe}^{3+}$ should be visualized (Evans et al., 1986). Ferric-reductase activities were calculated as the amount of product formed ( $\mathrm{mg}$ wet cell weight $)^{-1} \mathrm{~min}^{-1}$. The results represent the means of four experiments performed in duplicate.

Ferricyanide reduction, transport and excretion of soluble reducing reagents were measured by following the decrease in $A_{420}$ at room temperature $\left(24^{\circ} \mathrm{C}\right)$ using the methods described by Ecker \& Emery (1983), without adjusting $\mathrm{pH}$ in transport studies.

Protein determination. Protein concentrations were determinated with the Bio-Rad protein assay kit, based on the method of Bradford (1976), with bovine serum albumin as standard.

PAGE. Non-denaturing discontinuous PAGE was performed by following the protocol of Laemmli (1970) without SDS in the gels and buffers and using $12.5 \%(\mathrm{w} / \mathrm{v})$ acrylamide in the separating gel and $3.5 \%(\mathrm{w} / \mathrm{v})$ in the stacking gel. The cytoplasmic fraction (in buffer without $\mathrm{MgSO}_{4}$, plus $10 \mu \mathrm{g}$ PMSF ml ${ }^{-1}$ and $\left.0.2 \mathrm{mg} \mathrm{DNase} \mathrm{II} \mathrm{ml}^{-1}\right)(20 \mu \mathrm{l})$ was diluted with $20 \mu \mathrm{l}$ sample buffer containing $10 \mathrm{mM}$ Tris $/ \mathrm{HCl}(\mathrm{pH} \mathrm{7.5)}, 30 \%$ $(\mathrm{v} / \mathrm{v})$ glycerol and $0.01 \%$ bromophenol blue as the tracking dye. The sample $(30 \mu \mathrm{l})$ containing $90-100 \mu \mathrm{g}$ protein was applied to the gel. The gel was run at $32 \mathrm{~mA}$ (stacking gel) and $37 \mathrm{~mA}$ (separating gel) for $4 \mathrm{~h}$ at $4^{\circ} \mathrm{C}$. After electrophoresis, the gel was removed from the apparatus and ferric-reductase activities were detected, at $37^{\circ} \mathrm{C}$ with shaking, by adding $100 \mathrm{ml}$ buffer A containing $0.45 \mathrm{mM} \mathrm{NADH}, 2 \mathrm{mM}$ ferrozine and $250 \mu \mathrm{M}$ iron as ferric dicitrate.

Starch gel electrophoresis. Starch gels were prepared using $11 \%(\mathrm{w} / \mathrm{v}$ ) starch in $50 \mathrm{mM}$ Tris, $385 \mathrm{mM}$ glycine. Each cell fraction $(20 \mu \mathrm{l})$ (in buffer $\mathrm{A}$, without $\mathrm{MgSO}_{4}$, plus $10 \mu \mathrm{g}$ PMSF $\mathrm{ml}^{-1}$ ) was diluted with $20 \mu \mathrm{l}$ sample buffer containing $10 \mathrm{mM}$ Tris $/ \mathrm{HCl}(\mathrm{pH} 7.5)$ and $30 \%(\mathrm{v} / \mathrm{v})$ glycerol, and applied to the gel using a piece of Whatman no. 3 paper. The gels were run at $20 \mathrm{~mA}$ for $30 \mathrm{~min}$. The paper was then removed and the electrophoresis was continued for $6 \mathrm{~h}$. Ferric-reductase activities were detected as described above for native polyacrylamide gels.

Materials. Ferric chelates (ferric-NTA and ferric-EDTA) were prepared by mixing NTA or EDTA with equimolar concentrations of $\mathrm{FeCl}_{3}$ in deionized water. Ferric dicitrate was prepared by mixing sodium citrate with ferric chloride (200:1) in deionized water.

\section{RESULTS}

\section{$\mathrm{Fe}^{3+}$ reduction by whole cells}

Several $V$. anguillarum strains belonging to serotype groups $\mathrm{O} 1$ and $\mathrm{O} 2$ were assayed for their ferric-reductase activity when grown in iron-deficient and iron-rich conditions using ferrozine as $\mathrm{Fe}^{2+}$-trapping reagent (Table 1).

All strains reduced $\mathrm{Fe}^{3+}$ in different chelates, with a greater activity on ferric dicitrate in strains belonging to 
Table 1. Specific ferric-reductase activities in whole-cell preparations (cell density about $10^{9}$ c.f.u.) of $V$. anguillarum strains grown in CM9 without or with iron added as $5 \mu \mathrm{M}$ ferric dicitrate

Specific activities are expressed as $\mathrm{nmol} \mathrm{Fe}{ }^{2+}$-ferrozine formed $\mathrm{min}^{-1}$ (mg wet $\left.\mathrm{wt}\right)^{-1}$. The results are the means of four experiments in which each sample was determined in duplicate. All standard deviations were within $10 \%$ of the mean.

\begin{tabular}{|c|c|c|c|c|c|c|c|c|}
\hline \multirow[t]{3}{*}{ Strains } & \multicolumn{8}{|c|}{ Reduction of iron compounds } \\
\hline & \multicolumn{4}{|c|}{ Cells grown without iron } & \multicolumn{4}{|c|}{ Cells grown with iron } \\
\hline & $\mathrm{Fe}^{3+}$ dicitrate & $\mathrm{FeCl}_{3}$ & $\mathbf{F e}^{3+}-\mathbf{N T A}$ & $\mathrm{Fe}^{3+}-\mathrm{EDTA}$ & $\mathrm{Fe}^{3+}$ dicitrate & $\mathrm{FeCl}_{3}$ & $\mathbf{F e}^{3+}-\mathbf{N T A}$ & $\mathrm{Fe}^{3+}-\mathrm{EDTA}$ \\
\hline 775 & $0 \cdot 17$ & 0.03 & 0.06 & 0.05 & 0.55 & $0 \cdot 08$ & $0 \cdot 21$ & $0 \cdot 14$ \\
\hline $\mathrm{H} 775-3$ & $0 \cdot 16$ & 0.05 & 0.07 & $0 \cdot 05$ & $0 \cdot 51$ & $0 \cdot 17$ & $0 \cdot 18$ & $0 \cdot 15$ \\
\hline RV22 & 0.06 & 0.03 & 0.04 & $0 \cdot 12$ & 0.08 & $0 \cdot 03$ & 0.06 & $0 \cdot 16$ \\
\hline NG-6 & 0.02 & 0.01 & $0 \cdot 01$ & 0.06 & $0 \cdot 04$ & $0 \cdot 02$ & 0.03 & 0.09 \\
\hline
\end{tabular}

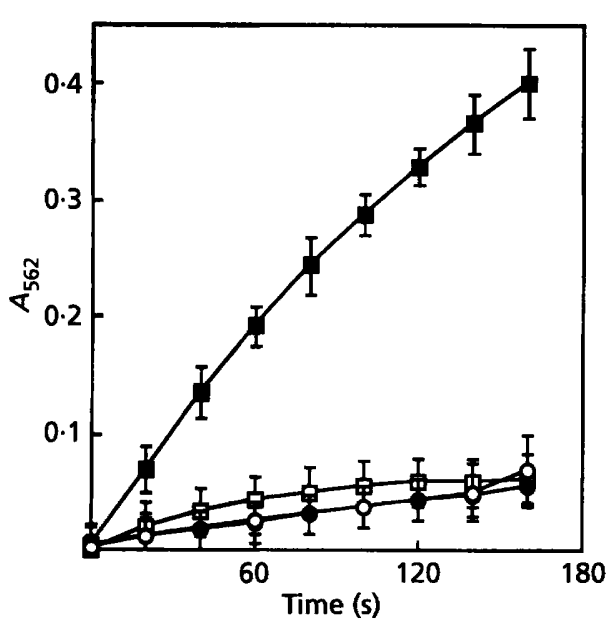

Fig. 1. Ferric dicitrate reduction by $V$. anguillarum strain $\mathrm{H} 775-3$ grown in CM9 medium with $5 \mu \mathrm{M}$ (as iron) ferric dicitrate. $\square$. Reduction at $24^{\circ} \mathrm{C} ; 0$, reduction at $4^{\circ} \mathrm{C}$; O, reduction in the presence of sodium azide $(20 \mathrm{mM}) ; \square$, reduction in the presence of DNP $(10 \mathrm{mM})$. Points represent the means of four experiments carried out in duplicate. Vertical bars indicate standard deviations for each point.

serotype group $\mathrm{O} 1$ and on ferric-EDTA in $\mathrm{O} 2$ strains. No spontaneous reduction of $\mathrm{Fe}^{3+}$ was observed in cellfree controls or when the bacterial cells were incubated with ferrozine alone without any added iron chelate. Strains from serotype group O1 showed a greater ferricreductase activity than $\mathrm{O} 2$ strains, except on ferricEDTA.

The ferric-reductase activity after growth in CM9 containing iron $(5 \mu \mathrm{M})$ as ferric dicitrate, ferric chloride, haemin or haemoglobin in cells from both serotypes was greater than in cells grown in CM9 alone. Thus, the presence of a source of iron in the growth medium increases the basal ferric-reductase activity of the cells.

The rate of reduction was strongly inhibited at $4{ }^{\circ} \mathrm{C}$ and in the presence of the respiratory inhibitor sodium azide $(20 \mathrm{mM})$ or the uncoupler DNP $(10 \mathrm{mM})$, as shown in

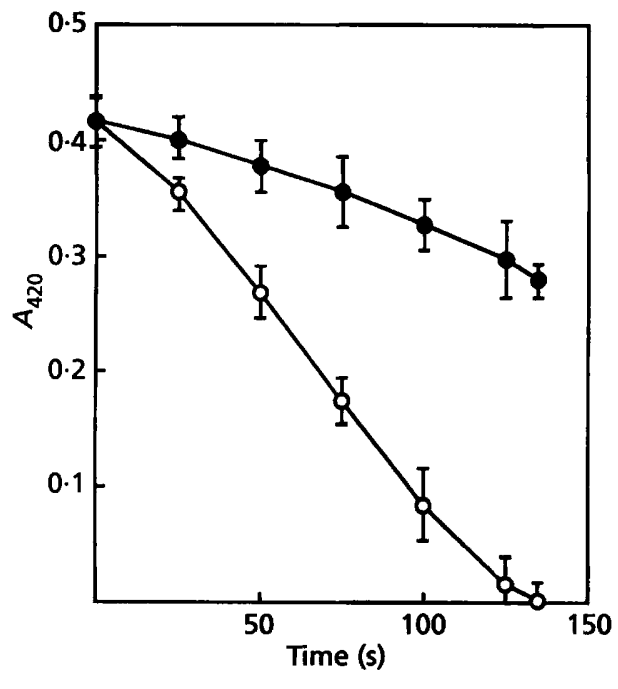

Fig. 2. Reduction of ferricyanide $(1.3 \mathrm{mM})$ by cells of $V$. anguillarum strain $\mathrm{H} 775-3$ grown in $\mathrm{CM} 9$ without $(O)$ and with (O) $5 \mu \mathrm{M}$ (as iron) ferric dicitrate. Points represent the means of four experiments carried out in duplicate. Vertical bars indicate standard deviations for each point.

Fig. 1 for the strain H775-3. Identical results were obtained with strains 775, RV22 and NG-6.

The possibility that cells could reduce substrates that are not transported was tested by the method of Ecker \& Emery (1983), using ferricyanide (final concentration of $1.3 \mathrm{mM}$ ) added to a culture of cells previously washed and resuspended in CM9. Strains from both serotypes reduced ferricyanide, with fivefold greater rates in group $\mathrm{O} 1$ strains than in serotype group O2 strains. Since ferricyanide is not able to penetrate cellular membranes, it is likely that this reductase capacity was also responsible for reduction of $\mathrm{Fe}^{3+}$ chelates (Ecker \& Emery, 1983). Ferricyanide reduction was also increased, over the basal reductase activity, when the cells were cultured in CM9 medium with iron added as ferric dicitrate, haemin or haemoglobin, as is shown in Fig. 2 for strain H775-3. 


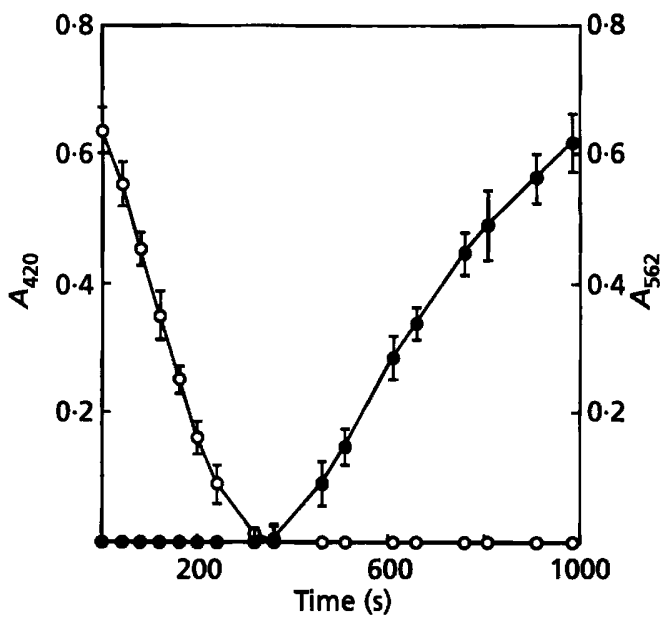

Fig. 3. Reduction of ferricyanide $(1.3 \mathrm{mM})(\mathrm{O})$ and $\mathrm{Fe}^{3+}$ $(12.5 \mu \mathrm{M})$ as ferric dicitrate $(0)$ by cells of $V$. anguillarum strain H775-3 grown in CM9 with $5 \mu \mathrm{M}$ (as iron) ferric dicitrate. Points represent the means of four experiments carried out in duplicate. Vertical bars indicate standard deviations for each point.

All strains tested reduced ferricyanide, although it appears to remain extracellular, since $97-99 \%$ of the ferricyanide colour was recovered in the medium supernatant using the method of Ecker \& Emery (1983). The possible excretion to the growth medium of a soluble compound with ferricyanide reductase activity was tested using sterile supernatants obtained from cultures of strains from both serotypes. No decrease in the $A_{420}$ (which indicates ferricyanide reduction) was observed over a period of $60 \mathrm{~min}$ in any strain. Thus, the reduction of this compound is associated with the cell surface.

When ferricyanide and ferric dicitrate were added sim- ultaneously to the bacterial cells resuspended in CM9, ferricyanide was reduced first followed by the reduction of ferric dicitrate, as shown in Fig. 3 for strain H775-3.

\section{$\mathrm{Fe}^{3+}$ reduction in cell fractions}

Cell-free extracts of $V$. anguillarum $\mathrm{H} 775-3$ grown aerobically in CM9 showed high rates of $\mathrm{Fe}^{3+}$ reduction, with higher values in the periplasmic and membrane fractions (Table 2). No spontaneous reduction of $\mathrm{Fe}^{3+}$ was observed in the absence of cell extracts.

The activities were assayed aerobically in crude extracts without addition of reductant and with NADH as potential electron donor for the enzyme. This compound was an effective cofactor for $\mathrm{Fe}^{3+}$ reduction, stimulating a 10-15-fold increase in reduction rates in the different fractions. The reductase activity was greatly inhibited (about $85 \%$ ) when $\mathrm{Mg}^{2+}$ was omitted from the assay buffer. NADPH was as effective as NADH in donating electrons to the reductase.

Ferric-reductase activities were completely destroyed in all fractions when the preparation was heated at $95^{\circ} \mathrm{C}$ for $15 \mathrm{~min}$ prior to the assay. The presence of iron in the growth medium did not have a clear effect on the ferricreductase activity in periplasmic and membrane fractions. However, there was an increase in reduction rate in the cytoplasm of cells grown in CM9 without added iron (Table 2). Addition of FAD to the assay buffer increased the ferric-reductase activities fivefold in the periplasm and cytoplasm and 15-fold in the membrane fractions. However, addition of sodium azide or DNP had no effect on the reductase activity of the membrane fractions.

Similar ferric-reductase activities were obtained with strain 775 , whereas in strain RV22 (serotype group O2) the reduction rates assayed using ferric dicitrate as iron source were lower: $1 / 3$ lower in the cytoplasm and $1 / 6$ lower in the membranes and periplasm.

Table 2. Specific activities of ferric-reductases in cell fractions from $\mathrm{H} 775-3$ grown in CM9 without $(-\mathrm{Fe})$ or with (+Fe) added iron, in a $\mathrm{Mg}^{2+}$-containing buffer and with $\mathrm{NADH}$ as reductant

Specific activity of ferric-reductase is expressed as $\mathrm{nmol} \mathrm{Fe}^{2+}$-ferrozine formed $\mathrm{min}^{-1}$ (mg protein) ${ }^{-1}$. The results are the means of four experiments in which each sample was determined in duplicate. All standard deviations were within $10 \%$ of the mean. NT, Not tested.

\begin{tabular}{|lllll|}
\hline Cell fraction & \multicolumn{4}{c|}{ Reduction of: } \\
\cline { 2 - 5 } & $\mathbf{F e}^{3+}$ dicitrate & $\mathbf{F e C l}_{3}$ & $\mathbf{F e}^{3+}-\mathbf{N T A}$ & $\mathbf{F e}^{3+}-\mathbf{E D T A}$ \\
\hline Cytoplasm & & & \\
$-\mathrm{Fe}$ & 0.83 & 0.51 & 0.39 & 0.34 \\
$+\mathrm{Fe}$ & 0.33 & 0.20 & 0.18 & 0.13 \\
Membranes & & & & \\
$-\mathrm{Fe}$ & 1.22 & 1.08 & 0.98 & $\mathrm{NT}$ \\
$+\mathrm{Fe}$ & 1.20 & 1.15 & 1.07 & $\mathbf{N T}$ \\
Periplasm & & & & \\
$-\mathrm{Fe}$ & 1.82 & 1.71 & 1.66 & $\mathbf{N T}$ \\
$+\mathrm{Fe}$ & 1.76 & 1.63 & 1.62 & $\mathrm{NT}$ \\
\hline
\end{tabular}


(a)
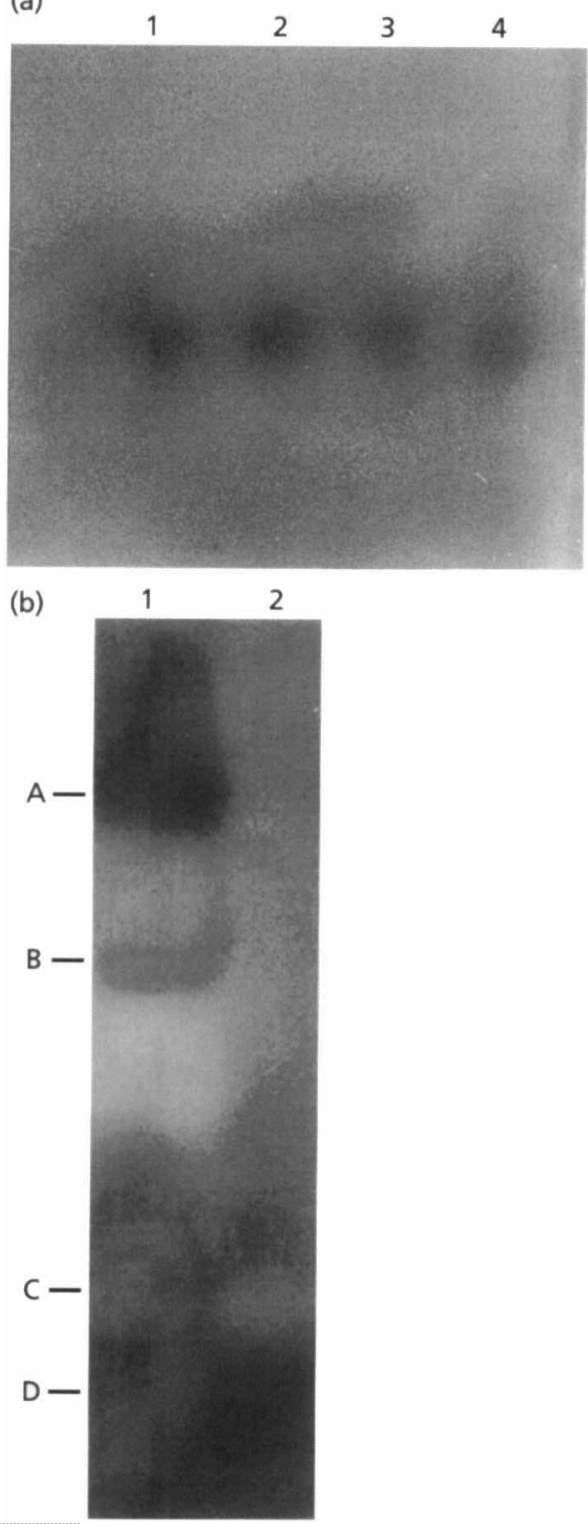

Fig. 4. Native discontinuous PAGE of ferric-reductase in the cytoplasmic fraction from (a) $V$. anguillarum strains $\mathrm{H} 775-3$ (lanes 1 and 4) and RV22 (lanes 2 and 3) and (b) E. coli HB101 (lane 1, bands A, B and C) and V. anguillarum H775-3 (lane 2, band $D$ ) with ferric dicitrate as iron source.

\section{Detection of ferric-reductases by native PAGE}

Assays of ferric-reductase activity in native polyacrylamide gels were performed with concentrated cytoplasmic, membrane and periplasmic fractions of $V$. anguillarum strains H775-3, 775, RV22 and NG-6 and E. coli HB101. Reductase activity could not be visualized in polyacrylamide gels of the periplasmic and membrane fractions. However, in the cytoplasmic fraction, a purple band in a pink background began to appear in all of the strain preparations after $20 \mathrm{~min}$ and was completely visible after $3 \mathrm{~h}$, as shown in Fig. 4(a) for H775-3 and RV22. In contrast in E. coli HB101, used for comparative purposes,

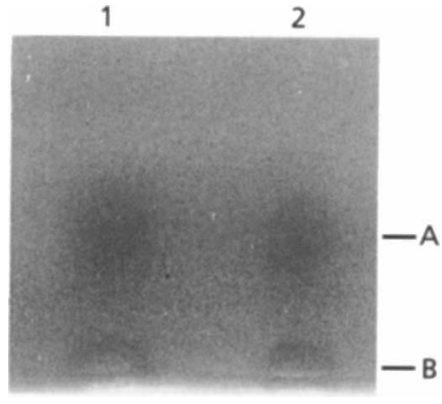

Fig. 5. Starch gel electrophoresis of ferric-reductases from the cytoplasm (A) and membrane/periplasm (B) fractions of $V$. anguillarum strains H775-3 (lane 1) and RV22 (lane 2) grown in CM9 with ferric dicitrate as iron source.

three bands appeared after that time (Fig. 4b). Although these bands were easily visualized by the naked eye, photographs of the gel were of poor contrast. Since H7753 and RV22 are plasmidless strains of $V$. anguillarum, this cytoplasmic reductase activity may be chromosomally encoded.

\section{Detection of ferric-reductases by starch gel electrophoresis}

Only a single band of reductase activity was visible in starch gels of membrane fractions from strains H775-3 and RV22 grown in CM9 with and without $5 \mu \mathrm{M}$ (as iron) ferric dicitrate. A band with identical mobility but of poor contrast was observed in the periplasmic fraction. When the whole-cell extracts from $\mathrm{H} 775-3$ and $\mathrm{RV} 22$ were applied to a starch gel, two bands were clearly visible. The band with the greatest mobility corresponded to the cytoplasmic reductase and the band with the lowest mobility to the membrane/periplasmic reductase(s) (Fig. 5). Identical results were obtained with strains 775 and NG-6 (data not shown).

\section{DISCUSSION}

This work demonstrates that $V$. anguillarum strains from serotype groups $\mathrm{O} 1$ and $\mathrm{O} 2$ can reduce $\mathrm{Fe}^{3+}$ in the form of different chelates, including ferric dicitrate. This ferricreductase activity was observed in whole cells as well as in cell fractions. In whole cells, the degree of reduction was dependent on the $\mathrm{Fe}^{3+}$ ligand and on the strain, with the greatest values corresponding to ferric dicitrate and serotype group O1 strains, respectively. The existence of differences in ferric-reductase activity between strains from serotype groups $\mathrm{O} 1$ and $\mathrm{O} 2$ is not surprising, since it is known that the siderophore-mediated iron-acquisition systems are different between strains of both serotypes (Lemos et al., 1988). Thus, the results reported here do confirm the existence of biochemical differences in the iron metabolism of both serotypes. Ferric-reductase activity in whole cells was induced when cells were grown in the presence of iron in the form of ferric dicitrate (Table 1 ), which suggests a reductive mechanism for utilization of iron from ferric dicitrate. However, this induction by 
iron is not observed in cellular fractions (Table 2). This could be explained by a possible alteration of the ferricreductase(s) associated with membranes during the cellfractionation process, in which the membrane structure is damaged. Also, an iron-inducible ferric-reductase could be detected in whole cells but not in cell fractions.

All of the strains tested could also reduce ferricyanide, a compound that is not transported into the cell but can cross the outer membrane of Gram-negative bacteria and thus can be reduced in the periplasm (Ingledew \& Poole, 1984). Ferricyanide reduction has also been described for Ustilago sphaerogena (Ecker \& Emery, 1983) and S. cerevisiae (Crane et al., 1982). Ferricyanide reduction was also increased when cells were grown in the presence of added iron, with the fastest reaction rates found in strains belonging to serotype group. $\mathrm{O} 1$, confirming the existence of differences in ferric-reductase activities between the two serotypes.

Ferric-reductase activity was detected in all of the cell fractions analysed, irrespective of the iron concentration of the growth medium, suggesting that ferric-reductase activity could be constitutive. However, in the cytoplasmic fraction some stimulation of activity $(2 \cdot 2-2 \cdot 6$ fold) occurred when the cells were grown in low-iron medium (Table 2). This could be explained if the cytoplasmic reductase was involved in the release of iron from ferrisiderophores. Since many of the components of the iron-uptake mechanism mediated by siderophores in $V$. anguillarum are regulated by iron (Crosa, 1989; Tolmasky \& Crosa, 1991), the cytoplasmic ferrisiderophore reductase could also be inhibited by the presence of $\mathrm{Fe}^{3+}$. Membrane and periplasmic reductases would not be involved in siderophore-based iron-uptake mechanisms, as they are not regulated by iron. In most microorganisms, the ferric-reductase activity is not regulated by iron (Fontecave et al., 1994), although in Neurospora crassa it is inducible under iron deficiency (Ernst \& Winkelmann, 1977).

The presence of ferric-reductases in different cell fractions is not unusual, although in most micro-organisms the ferric-reductase activity is associated only with the cytoplasm (Fontecave et al., 1994). In Pseudomonas aeruginosa, a ferripyochelin reductase was detected mainly in the cytoplasm, although it was also detected in the periplasmic and membrane fractions (Cox, 1980); in Legionella pneumophila (Johnson et al., 1991), $\mathrm{Fe}^{3+}$ reduction was also detected in all of the cell fractions. The membraneassociated ferric-reductase activity must be located mainly in the inner membrane, since our data (unpublished observations) indicate that ferric-reductase activity is not detectable in the outer membrane of $V$. anguillarum grown under aerobic conditions. Similar observations have been reported previously by Myers \& Myers $(1992,1993)$ for Shewanella putrefaciens, where ferric-reductases, which are part of the anaerobic respiratory chain, are detected in the outer membrane of cells grown under anaerobic, but never under aerobic, conditions.

All assays with cell fractions were performed under aerobic conditions, although it is known that in many micro-organisms ferric-reductase activities can only be detected under strict anaerobiosis (Myers \& Myers, 1993; Fontecave et al., 1994). However, in $P$. aeruginosa the cytoplasmic ferric citrate reductase is active in the presence of $\mathrm{O}_{2}(\mathrm{Cox}, 1980)$. This also seems to be true for reductases located in cell fractions of L. pneumophila (Poch \& Johnson, 1993) and a Rbizobium sp. (Roy et al., 1994). Moreover, in this study we found that the reductase activities (with ferric dicitrate as iron source) were maximal when the assay buffer contained NADH, $\mathrm{Mg}^{2+}$ and $\mathrm{FAD}^{+}$. This is not surprising, since in many other micro-organisms the presence of a free flavin (FMN or FAD) has been shown to actively stimulate the enzymic reduction by NADH (or NADPH) of many ferric ligands (Fontecave et al., 1994).

Neither DNP nor sodium azide inhibited the enzymic activity in the cell fractions assayed. However, $\mathrm{Fe}^{3+}$ reduction by whole cells was strongly decreased in the presence of these compounds (Fig. 1). These results could be explained if both compounds were energetic inhibitors of $\mathrm{Fe}^{3+}$ transport across the outer membrane to the periplasm/membrane reductases. In fact, the role of DNP as a protonophore is well known, collapsing the cytoplasmic membrane electrochemical potential and thus preventing active transport across the outer membrane (Jaskula et al., 1994).

As discussed above, some of the ferric-reductase activities observed in $V$. anguillarum could be involved in the mechanism of iron release from ferrisiderophores in the cytoplasm, as occurs in other micro-organisms (Emery, 1987). However, this reductive mechanism could also be used by $V$. anguillarum to obtain iron from other ligands (including ferric dicitrate) by a siderophore-independent mechanism. In that case, the function of the reductase would be to reduce external $\mathrm{Fe}^{3+}$, followed by $\mathrm{Fe}^{2+}$ transport to the cytoplasm by means of a transmembrane $\mathrm{Fe}^{2+}{ }_{-}$transport system, as has been proposed for Streptococcus mutans (Evans et al., 1986), S. cerevisiae (Lesuisse et al., 1987, 1991) and Listeria monocytogenes (Adams et al., 1990). In fact, our data (unpublished observations) indicate that although $V$. anguillarum cells can grow with ferric dicitrate as the only iron source, and that iron from ferric dicitrate is actually transported into the cell, both activities are strongly inhibited in the presence of $5 \mathrm{mM}$ ferrozine (a strong $\mathrm{Fe}^{2+}$-trapping reagent) (70\% inhibition) or $10 \mathrm{mM}$ ferricyanide (a competitive inhibitor) ( $90 \%$ inhibition). However, this growth reduction is not appreciable when a different iron source, such as haemoglobin, is used. These observations would suggest that an external reduction step would be necessary for utilization of $\mathrm{Fe}^{3+}$ from ferric dicitrate complexes.

Since $V$. anguillarum can survive for long periods in sea water (Muroga et al., 1986; Hoff, 1989), $\mathrm{Fe}^{3+}$ reduction from different iron chelates could constitute an additional mechanism to obtain iron from the marine environment, where the siderophore-mediated systems are probably not very effective.

In conclusion, $V$. anguillarum possesses intrinsic ferricreductase activities that can be detected in whole cells as 
well as in different cell fractions. These could be involved in the different systems of iron uptake by the cell, although other roles in cellular biochemistry cannot be ruled out. Further work is under way to elucidate the precise role of the reductase(s) in iron acquisition by this microorganism.

\section{ACKNOWLEDGEMENTS}

This work was supported by grants XUGA26202A93 and XUGA26202B95 from Xunta de Galicia (Spain) to M.L. R.M. also thanks Consellería de Educación, Xunta de Galicia, for a predoctoral fellowship.

\section{REFERENCES}

Adams, T. J., Vartivarian, S. \& Cowart, R. E. (1990). Iron acquisition systems of Listeria monocytogenes. Infect Immun 58, 27152718.

Angerer, A., Klupp, B. \& Braun, V. (1992). Iron transport systems of Serratia marcescens. J Bacteriol 174, 1378-1387.

Bradford, M. M. (1976). A rapid and sensitive method for the quantitation of microgram quantities of protein utilizing the principle of protein-dye binding. Anal Biochem 72, 248-254.

Conchas, R. D. (1994). Distribución de los sistemas de transporte de bierro en cepas de Vibrio anguillarum patógenas para peces y su implicación en la virulencia. $\mathrm{PhD}$ thesis, University of Santiago.

Cox, C. D. (1980). Iron reductases from Pseudomonas aeruginosa. J Bacteriol 141, 199-204.

Crane, F. L., Roberts, H., Lianne, A. W. \& Low, H. (1982). Transmembrane ferricyanide reduction by cells of the yeast Saccharomyces cerevisiae. J Bioenerg Biomembr 14, 191-205.

Crosa, J. H. (1989). Genetics and molecular biology of siderophore mediated iron transport in bacteria. Microbiol Rev 53, 517-530.

Dailey, H. A. \& Lascelles, J. (1977). Reduction of iron and synthesis of protoheme by Spirillum itersonii and other organisms. $J$ Bacteriol 129, 815-820.

Ecker, D. J. \& Emery, T. (1983). Iron uptake from ferrichrome A and iron citrate in Ustilago sphaerogena. J Bacteriol 155, 616-622.

Emery, T. (1987). Reductive mechanisms of iron assimilation. In Iron Transport in Microbes, Plants and Animals, pp. 235-250. Edited by G. Winkelmann, D. van der Helm \& J. B. Neilands. Weinheim: VCH Verlagsgesellschaft.

Ernst, J. \& Winkelmann, G. (1977). Enzymatic release of iron from sideramines in fungi, NADH-sideramine oxidoreductase in Neurospora crassa. Biochim Biopbys Acta 500, 27-41.

Evans, S. L., Arcenaux, J. E. L., Byers, B. R. \& Mark, M. E. (1986). Ferrous iron transport in Streptococcus mutans. J Bacteriol 168, 1096-1099.

Fischer, E., Strehlow, B., Hartz, D. \& Braun, V. (1990). Soluble and membrane-bound ferrisiderophore reductases of Escherichia coli $\mathrm{K}$ 12. Arch Microbiol 153, 329-336.

Fontecave, M., Covès, J. \& Pierre, J. L. (1994). Ferric reductases or flavin reductases? BioMetals 7, 3-8.

Hallé, F. \& Meyer, J.-M. (1989). Ferripyoverdine-reductase activity in Pseudomonas fluorescens. Biol Metals 2, 18-24.

Hoff, K. A. (1989). Survival of Vibrio anguillarum and Vibrio salmonicida at different salinities. Appl Environ Microbiol 55, 1775 1786.
Ingledew, W. J. \& Poole, R. K. (1984). The respiratory chains of Escherichia coli. Microbiol Rev 48, 222-271.

Jaskula, J. C., Letain, T. E., Roof, S. K., Skare, J. T. \& Postle, K. (1994). Role of the Ton $B$ amino terminus in energy transduction between membranes. J Bacteriol 176, 2326-2338.

Johnson, W., Varner, L. \& Poch, M. (1991). Acquisition of iron by Legionella pneumophila: role of an iron reductase. Infect Immun 59, $2376-2386$.

Laemmli, U. K. (1970). Cleavage of structural proteins during the assembly of the head of bacteriophage T4. Nature 227, 680-685.

Lascelles, J. \& Burke, K. A. (1978). Reduction of ferric iron by Llactate and DL-glycerol-3-phosphate in membrane preparations from Stapbylococcus aureus and interactions with the nitrate reductase system. J Bacteriol 134, 585-589.

Lemos, M. L., Salinas, P., Toranzo, A. E., Barja, J. L. \& Crosa, J. H. (1988). Chromosome-mediated iron-uptake system in pathogenic strains of Vibrio anguillarum. J Bacteriol 170, 1920-1925.

Lesuisse, E., Raguzzi, F. \& Crichton, R. R. (1987). Iron uptake by the yeast Saccharomyces cerevisiae : involvement of a reduction step. J Gen Microbiol 133, 3229-3236.

Lesuisse, E., Horion, B., Labbe, P. \& Hilger, F. (1991). The plasma membrane ferric-reductase activity of Saccharomyces cerevisiae is partially controlled by cyclic AMP. Biochem J 280, 545-548.

Mazoy, R. \& Lemos, M. L. (1991). Iron-binding proteins and heme compounds as iron sources for Vibrio anguillarum. Curr Microbiol 23, 221-226.

Mazoy, R. \& Lemos, M. L. (1996). Identification of heme-binding proteins in the cell membranes of Vibrio anguillarum. FEMS Microbiol Lett 135, 265-270.

Miller, J. H. (1972). Experiments in Molecular Genetics. Cold Spring Harbor, NY: Cold Spring Harbor Laboratory.

Moody, M. D. \& Dailey, H. A. (1983). Aerobic ferrisiderophore reductase assay and activity stain for native polyacrylamide gels. Anal Biochem 134, 235-239.

Muroga, K., lida, M., Matsumoto, H. \& Nakai, T. (1986). Detection of Vibrio anguillarum from waters. Bull Jpn $S_{o c} S_{c i}$ Fish 52, 641-647.

Myers, C. R. \& Myers, J. M. (1992). Localization of cytochromes to the outer membrane of anaerobically grown Shewanella putrefaciens MR-1. J Bacteriol 174, 3429-3438.

Myers, C. R. \& Myers, J. M. (1993). Ferric teductase is associated with the membranes of anaerobically grown Shewanella putrefaciens MR-1. FEMS Microbiol Lett 108, 15-22.

Neilands, J. B., Konopka, K., Schwyn, B., Coy, M., Francis, R. T., Paw, H. \& Bagg, A. (1987). Comparative biochemistry of microbial iron assimilation. In Iron Transport in Microbes, Plants and Animals, pp. 235-250. Edited by G. Winkelmann, D. van der Helm \& J. B. Neilands. Weinheim: VCH Verlagsgesellschaft.

Poch, M. T. \& Johnson, W. (1993). Ferric reductases of Legionella pneumopbila. BioMetals 6, 107-114.

Roy, N., Bhattacharyya, P. \& Chakrabartty, K. (1994). Iron acquisition during growth in an iron-deficient medium by $\mathrm{R} b i$ zobium sp. isolated from Cicer arietinum. Microbiology 140, 2811-2820.

Stookey, L. L. (1970). Ferrozine - a new spectrophotometric reagent for iron. Anal Chem 42, 779-781.

Tolmasky, M. E. \& Crosa, J. H. (1991). Regulation of plasmidmediated iron transport and virulence in Vibrio anguillarum. BioMetals 4, 33-35.

Received 28 November 1995; revised 3 July 1996; accepted 11 July 1996. 